\footnotetext{
References

1. Kharoua, N., Khezzar, L., Saadawi, H. (2013) CFD Modelling of a Horizontal Three-Phase Separator: A Population Balance Approach, American Journal of Fluid Dynamics, 3(4), 101-118. doi: 10.5923/j.ajfd.20130304.03.

2. Pourahmadi Laleh, A., Svrcek, W. Y., \& Monnery, W. (2013, February 1). Computational Fluid Dynamics-Based Study of an Oilfield Separator--Part II: An Optimum Design. Society of Petroleum Engineers. doi:10.2118/161036-PA

3. Pourahmadi Laleh, A., Svrcek, W. Y., \& Monnery, W. (2012, December 1). Computational Fluid Dynamics-Based Study of an Oilfield Separator--Part I: A Realistic Simulation. Society of Petroleum Engineers. doi:10.2118/161212-PA

4. Liaposhchenko, O.O., Pavlenko, I.V., Demianenko, M.M., Starynskyi, O.Ye. (2018, April 24 - 27) Hydrodynamics simulation and forecasting the efficiency of separation equipment oil stabilization unit of Gnidyntsy gas processing plant / II International Scientific and Technical Conference "Machines, Equipment and Materials for Oil and Gas Production Increase" PGE, Ivano Frankivsk, P. 340 - 342.

5. Pat. 111039. Sposib vlovliuvannia vysokodyspersnoi kraplynnoi ridyny $\mathrm{z}$ hazoridynnoho potoku / Liaposhchenko, O.O., Nastenko, O.V., Pavlenko, I.V., Demianenko, M.M., Starynskyi, O.Ye. (Ukraina).

6. Pavlenko, I.V., Demianenko, M.M., Starynskyi, O.Ye., Kovtun, V.V., Borisova, N.V. (2018, April 17 - 20). Optymizaciine komponuvannia tryfaznykh separatoriv dlia ustanovok stabilizacii vuhlevodnevoi syrovyny.: vseukrainska mizhvuzivska naukovotekhnichna konferenciia (m. Sumy, 17 - 20 kvitnia 2018 r.) (pp. 232). Sumskui derzhavnyi universytet.

7. Liaposhchenko, O.O., Pavlenko, I.V., Usyk, R.Yu., Demianenko, M.M. (2015). Modeliuvannia procesiv separacii ta rozrobka metodyky rozraxunku trifaznoho separatora. Naukovi pratsi odeskoi natsionalnoi akademii Kharchovykh tekhnolohii : naukovyi zhurnal seriia tekhnichni nauky, No. 47, pp. 62-66.

8. Sloboda, O., Korba, P., Hovanec, M., Pila, J. Numerical approach in aeroelasticity. Scientific Journal of Silesian University of Technology. Series Transport. 2016, 93, 115-122. doi: https://doi.org/10.20858/sjsutst.2016.93.12
}

Отримано в редакцію 11.05.2018

Прийнято до друку 30.06.2018

УДК 663.26
Received 11.05.2018

Approved 30.06.2018

\title{
АПАРАТИ ДЛЯ РОЗДІЛЕННЯ ПРОДУКТІВ ВИНОРОБСТВА
}

\author{
Ковалевський К.А., проф., к.т.н., Валько М.І., проф., д.т.н., Мамай О.І., доц., к.т.н., Кузьміна \\ Т.О., проф., д.т.н., Яковенко Т.О., ассистент.
}

Херсонський національний технічний університет, м. Херсон

\begin{abstract}
Анотація. В статті наводяться результати досліджень щзодо застосування гідроциклонів для відокремлення твердих частинок з виноградного сусла, виноградного насіння з вичавок, а також для освітлення дифузійного соку після екстракиії виноградних вичавок, стічних вод та інших забруднених рідин. В результаті проведених досліджень визначені оптимальні параметри гідроциклонів при відокремленні різних твердих частинок. Запропоновано режими роботи гідроциклонів, при яких досягаються максимальні ефекти розподілу. Для розподілу використовуються різні конструкиї гідроциклонів, з регулюванням отвору виходу осадів з обертовим активатором, тощзо.
\end{abstract}

Ключові слова: виноградне насіння, сусло, обертовий активатор, ефект розподілу.

\section{THE DEVICES FOR SEPARATION OF WINE PRODUCTS}

\author{
Kovalevskiy K.A., PhD in Tech.Sci., prof., Valko M.I., Dr. of Tech.Sci., prof., Mamay O.I., PhD in \\ Tech.Sci., Asosiate prof., Kuzmina T.O., Dr. of Tech.Sci., prof., Yakovenko T.O., assistant
} Kherson National Techikal University, Kherson, Ukraine

Abstract. The article presents the results of research on the use of hydrocyclones for the separation of solid
grapevine particles, grape seeds from squashes, as well as for the diffusion juice illumination after the extraction
of grape vinegar, sewage and other contaminated liquids. Studies were conducted on the separation of grape
seeds mixed with yeast bard.
To achieve the desired effect of separation on the hydrocyclone it is necessary to thoroughly analytically
ground and experimentally determine the necessary parameters of the size of its parts. One way to regulate the
separation of solid particles from winemaking products is to change the size of the opening of the lower drain
fitting or to change the design of the conical part.
The construction of a hydrocyclone with a controlled opening of sediments was found to be used to separate
solids from grape and fruit berries (juice), separation of lime vine. In addition, with this design, it is possible to
determine the structural dimensions of the hydrocyclones for other products, for example, to separate the grape
seed from the flow of water with squeegees.
As a result of the researches, optimal parameters of the hydrocyclones were determined at separation of 


\section{Одеська національна академія харчових технологій ІННОВАЦЙНЕ ОБЛАДНАННЯ ХАРЧОВИХ, ФАРМАЦЕВТИЧНИХ, ХІМІЧНИХ ТА ПАРФУМЕРНИХ ВИРОБНИЦТВ}

various solid particles. The modes of operation of hydrocyclones, in which the maximum distribution effects are achieved, are proposed. Different structures of the hydrocyclones are used for distribution, with adjustment of the opening of sediment release with a rotary activator, and others like that. Due to the improvement of flow distribution at the entrance to the hydrocyclone, increasing the speed of the flow of the activator, the effect of cleaning the suspension from impurities increases by 15-20\%.

The use of a hydrocyclone for the separation of suspensions of tartaric lime makes it possible to completely separate impurities with minor losses.

To study the efficiency of the distribution of each product it is necessary to conduct a test of hydrocyclone with increased height and diameter of the cylindrical part of the body, the conical part with different angles of conicality and the size of the aperture for the lower drain of glass.

Keywords: grape seeds, wort, adjustable cross section, rotating activator, separation effect, hydrocyclone.

Вступ. Гідроциклони відносяться до класу вихрових апаратів, призначених для поділу рідких неоднорідних систем (суспензій, нестійких емульсій та газовмісних рідин) в полі відцентрових сил [1]. Завдяки простоті конструкції, компактності, високій питомій продуктивності та надійності, гідроциклони набули широкого застосування в хімічній, нафтовидобувній, гірничорудній, харчовій галузях, в енергетиці, металургії, а також в системах очищення промислових і побутових стічних вод [2]. Ці апарати вигідно відрізняються можливістю застосування в безперервних замкнутих технологічних циклах і в безвідходних виробництвах із забезпеченням порівняно високої якості розділення сумішей. Фактор поділу в гідроциклонах становить 500 ... 2000, а в гідроциклонах і мультициклонах високого тиску - до 5000.

Аналіз проблематики та літературних джерел. Практичне застосування гідроциклонів в ряді галузей промисловості (цукровій, крохмале-патоковій, олійно-жировій, консервній та ін.), а також позитивні результати досліджень з освітлення сусла і виноматеріалів, суспензій при переробці вторинних продуктів виноробства свідчать про можливість використання цього типу апаратів у виноробстві. Гідроциклони застосовувались у виноробстві для відокремлення виннокислого вапна від маточного розчину, для відокремлення завислих частинок від сусла при подачі його на сепаратор, для очищення цукрового сиропу в плодово-ягідному виробництві, для відокремлення кристалів винного каменю з виноматеріалу і ін. [3-5]. За кордоном гідроциклони на винзаводах використовуються, як правило, для видалення піску із сусла i захисту від зношування дорогих барабанів сепараторів [6,7].

До преваг гідроциклонів відносять простоту конструкції, відсутність обертових частин, малі габаритні розміри і велику продуктивність. Проте, незважаючи на простоту конструкції гідроциклону, розробка працездатного та надійного апарату вимагає проведення великого комплексу експериментальних робіт. Практика застосування гідроциклонів показує, що досвід їх установки не можна механічно переносити 3 одного проекту на інший. Впровадження і використання гідроциклонів у виноробстві стримується також відносно низьким у порівнянні з іншими апаратами ефектом розподілу фракцій.

Конструкція гідроциклону складається з циліндроконічного корпусу з двома штуцерами для введення рідини і виведення іiі після відокремлення твердих частинок та отворів в нижній частині корпусу. Для досягнення необхідного ефекту поділу на гідроциклоні необхідно ретельно аналітично обгрунтувати і експериментально визначити необхідні параметри розмірів його частин.

Одним із шляхів регулювання процесу відокремлення твердих частинок із продуктів виноробства $\epsilon$ зміна розміру отвору штуцера нижнього зливу або зміна конструкції конічної частини.

Метою цієї роботи було визначення впливу параметрів гідроциклонів різної конструкції на ефективність відокремлення твердих частинок із різних продуктів виноробства.

Експериментальні дослідження. Обговорення результатів. Дослідження проводили на гідроциклонах, принципові схеми яких приведено на рис. 1, 2, 3.

Конструкція гідроциклону з регульованим отвором виведення осадів знайшла застосування для відокремлення твердих включень від виноградного і плодово-ягідного сусла (соку), відокремлення виннокислого вапна. Крім цього за допомогою такої конструкції можна визначати конструктивні розміри гідроциклонів для інших продуктів, наприклад, для відокремлення виноградного насіння 3 потоку води 3 вичавками.

В результаті проведених досліджень були визначені оптимальні конструктивні розміри гідроциклонів при відокремленні різних твердих частинок. Результати представлені в табл.1.

Гідроциклон з регульованим отвором виведення осадів (рис.1) складається з наступних елементів: 1 конічна частина корпусу; 2 - циліндрична частина корпусу; 3 - вузол виведення освітленої частини продукту; 4 - стрижень клапану регулювання отвору виходу осадів: 5 - частина стрижня з різьбленням; 6 контргайка; 7 - штуцер виведення освітленого продукту; 8 - штуцер введення продукту; 9 - клапан. D внутрішній діаметр циліндричної частини; $\mathrm{D}_{\text {узв }}$ - діаметр патрубка верхнього зливу; $\mathrm{d}$ - діаметр нижнього 
Одеська національна академія харчових технологій

ІННОВАЦІЙНЕ ОБЛАДНАННЯ ХАРЧОВИХ, ФАРМАЦЕВТИЧНИХ, ХІМІЧНИХ ТА ПАРФУМЕРНИХ ВИРОБНИЦТВ

зливу; $\mathrm{d}_{\mathrm{вx}}$ - діаметр патрубка входу суспензії; $\mathrm{d}_{\text {вих }}$ - діаметр патрубка виходу суспензії; $\mathrm{d}_{\text {гл }}$ діаметр стрижня; $\mathrm{H}_{\text {кон }}$ - висота конуса; $\mathrm{H}_{\text {цил }}$ - висота циліндричної частини; $\mathrm{a}^{\circ}$ - конусність.

Раніше був запропонований гідроциклон для освітлення дифузійного соку, отриманого на екстракторі безперервної дії Р3-BEA [8] (рис. 2), а також дослідна модель гідроциклону з обертовим стрижнем і активатором (рис. 3) [9].

Гідроциклон для освітлення дифузійного соку (рис. 2) складається з циліндроконічної ємності 1 , що має конусну частину 2 для відведення осаду, тангенційно встановленого патрубку 4 для подачі дифузійного соку, що підлягає освітленню, патрубка 5 для відводу освітленої фази, штоку 8, встановленого всередині ємності 1 по іiї вісі, що закінчується голчастим клапаном і забезпеченого електромагнітним приводом.

Таблиця 1

Параметри гідроциклонів для різних твердих частинок

\begin{tabular}{|c|c|c|c|}
\hline Параметри, мм & $\begin{array}{c}\text { Для суспензій со- } \\
\text { ку, сусла }\end{array}$ & $\begin{array}{c}\text { Для виноградних кі- } \\
\text { сточок }\end{array}$ & $\begin{array}{c}\text { Для частинок каналі- } \\
\text { заційних стоків }\end{array}$ \\
\hline $\mathrm{D}$ & 60 & 100 & 120 \\
\hline $\mathrm{D}$ & 20 & 30 & 70 \\
\hline $\mathrm{D}_{\text {узв }}$ & 45 & 50 & 70 \\
\hline $\mathrm{d}_{\text {в }}$ & 40 & 50 & 70 \\
\hline $\mathrm{d}_{\text {вих }}$ & 40 & 50 & 226 \\
\hline $\mathrm{d}_{\text {гл }}$ & 8 & 10 & 40 \\
\hline $\mathrm{H}_{\text {кон }}$ & 143 & 198 & 20 \\
\hline $\mathrm{H}_{\text {цил }}$ & 20 & 30 & 20 \\
\hline $\mathrm{a}^{\circ}(г р а д)$ & 20 & 20 & \\
\hline
\end{tabular}

Останній складається з електромагніту 12 з тягою 11 , планки 14 , розміщеної на стійці 10 , пружини 15, що впливає на положення планки. Від переміщення вгору планки 14 , а, отже, і штока утримують гайки. Останні служать також для регулювання положення голчастого клапана по відношенню до отвору у конусній частині 2. Таким чином з їх допомогою можна регулювати розмір цього отвору.

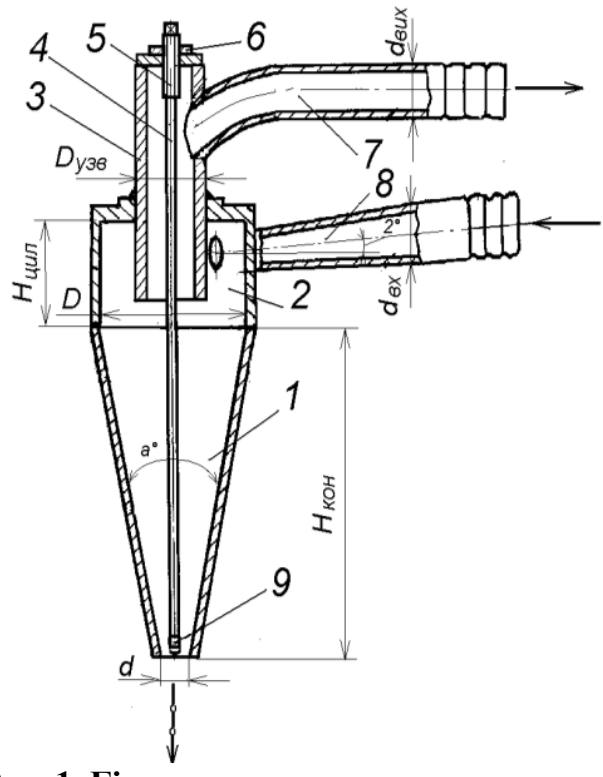

Рис. 1. Гідроциклон з регульованим отвором виведення осадів.

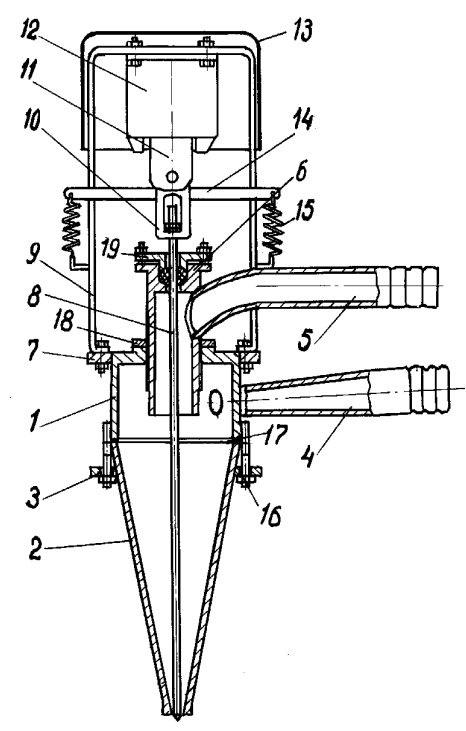

Рис. 2. Гідроциклон для освітлення дифузійного соку.

Працює гідроциклон наступним чином. В ємність 1 по патрубку 4 подається неосвітлений дифузійний сік. Під дією відцентрових сил, що виникають внаслідок завихрення рідини в ємності, домішки, що мають більшу щільність, ніж рідка фракція, відкидаються до периферії ємності і направляються по ії конічній частині 2 до вихідного отвору. Через кільцевий зазор, утворений краєм отвору 2 і голчастим клапаном 8 , осад виводиться з пристрою. Освітлений сік під дією тиску неосвітленого соку, що входить в гідроциклон, виводиться зовні по патрубку 5.

Осад поступово накопичується в нижній (конусній) частині гідроциклону. При цьому шток 8 конусним накінечником щільно закриває вихідний отвір, бо пружини 15 утримують планку 14 в 


\section{Одеська національна академія харчових технологій \\ ІННОВАЦЙНЕ ОБЛАДНАННЯ ХАРЧОВИХ, ФАРМАЦЕВТИЧНИХ, ХІМІЧНИХ ТА ПАРФУМЕРНИХ ВИРОБНИЦТВ}

потрібному положенні. Електромагнітний клапан виключений. В міру накопичення осаду в конусній частині або засмічення кільцевого отвору гідродинамічний тиск осаду на кінечник штоку 8 перевищує зусилля пружин. Шток з клапаном опускається вниз на 20-30 мм, а його верхній край тягне за собою тягу електромагніту і одночасно стискає врівноважувальні пружини. В отвір конусної частини продавлюється згусток осаду, що утворився. Як тільки тиск осаду на клапан штоку зменшиться електромагнітний клапан підтягне планку 14 у вихідне положення, а пружини 15 врівноважать і1і. Шток 8 разом 3 планкою 14 піднімається і закриває вихідний отвір конусної частини. Гідроциклон без зупинки продовжує працювати.

Проведені дослідження і випробування гідроциклону довели його ефективність. Суспензія, що містить 5-8\% завислих часточок перетертої вичавки та пропущена один раз крізь гідроциклон з подачею до $15 \mathrm{~m}^{3} /$ год, звільняється від домішок на 50-60\%. При цьому слід врахувати, що до складу завислих часточок входять і дрібні частини насіння. Повторне пропускання дифузійного соку крізь гідроциклон дозволяє очистити його на $30 \%$ від твердих частинок, що залишилися після першого очищення. Третє $\mathrm{i}$ четверте очищення дифузійного соку дають вельми незначні результати.

Гідроциклон перевірений також в роботі з розділенням суспензій виннокислого вапна (ВКВ). Використання гідроциклону з поверненням перших порцій освітленої рідини дозволяє повністю відокремити домішки з невеликими втратами. Гідроциклон з обертовим активатором призначений для очищення продуктів виноробства, стічних вод та інших забруднених рідин від крупних частинок (рис. 3). Його відмінністю є наявність обертового активатора, що виконує роль механізму для збільшення відцентрового впливу на частинки та роль рухомого (по вертикалі) клапана, що регулює вихідний отвір для осаду. 3 метою поліпшення розподілу сил, що сприяють підвищенню швидкості потоку, вхідний патрубок виконано у вигляді напівкільця з введенням суспензії крізь два діаметрально розташованих тангенціальних отвори в циліндричному корпусі.

Привід голки з активатором, що обертається, здійснюється від електродвигуна, встановленого на ковзаючому майданчику. Останній встановлено в направляючих стійках і з'єднано 3 гвинтовим механізмом пересування у вертикальному напрямку. Гідроциклон складається з циліндричного корпусу 1 3 пласкою кришкою зверху та фланцевим з'єднанням 2 знизу, яким з'єднується з конічним корпусом 3. По вісі циліндричного корпусу встановлено центральний патрубок 4. Конічний корпус 3 закінчується бобишкою з різьбленням, на якому кріпиться розтруб 5. Останній є і деталлю кріплення змінного патрубка 6 і втулки 7. По вісі циліндроконічного корпусу встановлена всередині голка 8 , із закріпленим на ній активатором 9.

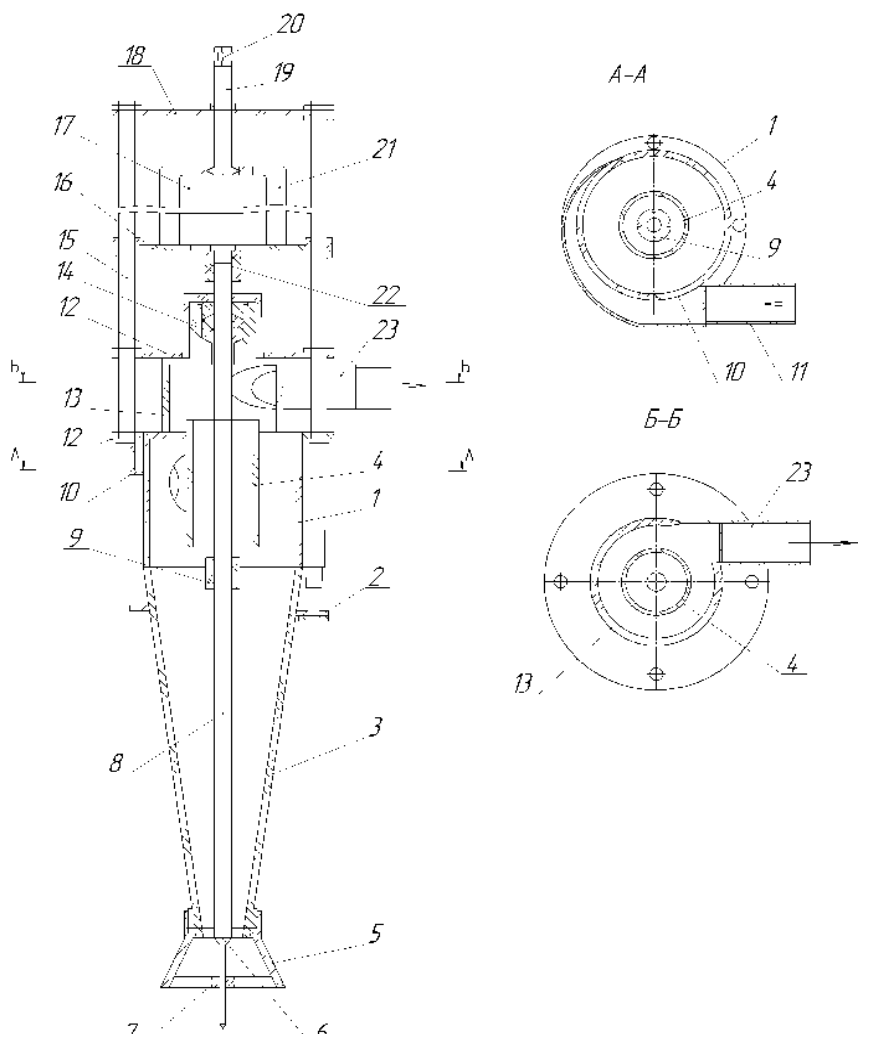

Рис. 3. Гідроциклон $з$ активатором, що обертається. 


\section{Одеська національна академія харчових технологій ІННОВАЦІЙНЕ ОБЛАДНАННЯ ХАРЧОВИХ, ФАРМАЦЕВТИЧНИХ, ХІМІЧНИХ ТА ПАРФУМЕРНИХ ВИРОБНИЦТВ}

В циліндричному корпусі виконано отвори 10, які розташовані діаметрально і врізані тангенціально щодо корпусу. До корпусу прикріплений напівциліндричний штуцер введення суспензії 11 . До кришки 12 циліндричного корпусу 1 кріпиться камера зливу 13, в яку з циліндричного корпусу введений центральний патрубок 4. Камера 13 зверху виконана у вигляді сальникового пристрою, що ущільнює зазор між корпусом і голкою 8. На стійках 15 жорстко закріплених до кришки 12 встановлено рухомий майданчик 16 електродвигуна 17. Стійки 15 зверху з'єднані хрестовиною 18 , в центрі якої встановлена бобишка 19 де кріпиться гвинт 20, шарнірно з'єднаний з майданчиком 16 і підвіскою 21 . Вал електродвигуна 17 з'єднаний з голкою 8 еластичною муфтою 22.

Працює такий гідроциклон наступним чином. Суміш виноградних вичавків з рідиною подається під тиском насосу 0,1-0,2 МПа через штуцер введення суспензії 11. Суспензія, розділена на два рівномірних потоки подається в циліндричний корпус, де обертаючись, опускається до зливного штуцера 6 . При цьому за рахунок відцентрових сил потік, що обертається, розподіляється за щільністю. Більш щільні частинки рухаються вниз по конічній поверхні і проходять крізь зливний штуцер, перекриваючи його. Більш легка фракція, обертаючись, піднімається вгору крізь центральний патрубок 4, камеру зливу 13 і патрубок верхнього зливу 23. Голка 18 обертається в напрямку обертання потоку, тому поверхнею встановленого на ній активатора 9 прискорює обертання рідини, яка піднімається до патрубку верхнього зливу. Цим самим поліпшується відокремлення від потоку рідини твердих частинок, що відкидаються в потік, який рухається по поверхні конічного корпусу. За допомогою гвинта 20, бобишки 19, закріпленої до приставки 18, майданчик 16 з встановленим на ньому електродвигуном 17 можна піднімати або опускати. Разом $з$ двигуном 17 пересувається у вертикальному напрямку і голка 8 з активатором 9. Таким чином регулюється отвір вхідного штуцера 6 і вихід осаду.

Для різних розчинів конічні корпуси були виготовлені з різною довжиною та кутом конусу. Голка під час обертання хвістовиком спирається на направляючу втулку 7, прикріплену до направляючого розтрубу 5, що дозволяє зменшити швидкість обертання осаду в момент його випуску.

Дослідження показали, що при одноразовому пропущенні суміші крізь гідроциклон ефект очищення досягає близько 50\%. Тому було прийнято рішення пропускати один і той же обсяг багаторазово крізь гідроциклон. Гідроциклон був виконаний в трьох варіантах: з різним кутом нахилу і різною довжиною конусу. Результати випробувань гідроциклону з відокремленням виноградного насіння наведені в табл. 2. Дані свідчать, що без голки активатора ефект очищення від насіння досягає $88 \%$, та найменша кількість рідини виходить із насінням. Досліди проводилися з дворазовим пропуском об'єму суспензії крізь гідроциклон (конус 1), а також збільшеною тривалістю процесу (конус 2). Збільшення часу проходження рідини крізь гідроциклон сприяє збільшенню ефекту відокремлення насіння.

Таблиця 2

Результати випробувань гідроциклону

\begin{tabular}{|c|c|c|c|c|}
\hline Вид сировини & $\begin{array}{c}\text { Тривалість } \\
\text { обробки, } \\
\text { хв }\end{array}$ & Оснащення гідроциклону & $\begin{array}{c}\text { Ефект відокре- } \\
\text { млення домі- } \\
\text { шок, \% }\end{array}$ & $\begin{array}{l}\text { Кількість } \\
\text { води } 3 \\
\text { осадом, \% }\end{array}$ \\
\hline \multicolumn{5}{|c|}{ Конус № 1} \\
\hline \multirow{3}{*}{$\begin{array}{c}\text { із завислими } \\
\text { частинками та } \\
\text { залишками на- } \\
\text { сіння }\end{array}$} & 6 & З голкою, що обертається & 88 & 3,5 \\
\hline & 6 & Без обертання голки & 88 & 3,5 \\
\hline & 6 & Без голки & 80 & 12,5 \\
\hline \multicolumn{5}{|c|}{ Конус № 2} \\
\hline \multirow{4}{*}{$\begin{array}{c}\text { із завислими } \\
\text { частинками та } \\
\text { залишками на- } \\
\text { сіння }\end{array}$} & 15 & З активатором, що обертається & 80 & 15 \\
\hline & 15 & Без голки та активатора & 72 & 7,5 \\
\hline & 15 & Без активатора з голкою, що обертається & 93 & 6,5 \\
\hline & 15 & Без обертання голки & 97 & 5 \\
\hline
\end{tabular}

Проводились також дослідження з відокремлення виноградного насіння, змішаного з дріжджовою бардою. Ефект очищення в даному випадку був вищий завдяки рівномірному розподілу насіння в усьому об'ємі рідини.

Висновки. Завдяки поліпшенню розподілу потоку на вході в гідроциклон, підвищенню швидкості обертання потоку активатором, ефект очищення суспензії від домішок збільшується на 15-20\%.

Для подальшого вивчення ефективності розподілу кожного продукту необхідно провести випробування гідроциклону зі збільшеною висотою і діаметром циліндричної частини корпусу, конічної частини з різними кутами конусності і величини отвору для нижнього зливу зі скла. Особливо це перспективно 


\title{
Одеська національна академія харчових технологій ІННОВАЦЙНЕ ОБЛАДНАННЯ ХАРЧОВИХ, ФАРМАЦЕВТИЧНИХ, ХІМІЧНИХ ТА ПАРФУМЕРНИХ ВИРОБНИЦТВ
}

при застосуванні гідроциклону для відокремлення насіння від рідини з легкими завислими частинками (шкіркою). Дослідження будуть продовжені.

\section{Література}

1. Касаткин А.Г. Основные процессы и аппараты химической технологии. М.: Химия. 1971. 784 с.

2. Боголюбский С.Д. Исследование работы гидроциклонов и их совершенствование. Экспресс-информация. Зарубежный опЫт. М.: ЦИНТИХИМНЕФТЕМАШ. 1986. 6 с.

3. Виноградов В.А. Оборудование винодельческих заводов. Симферополь: Таврида, 2002. Т. 1. 416 с.

4. Зайчик Ц.Р., Литвинов А.К., Казначеева О.А. Применение гидроциклонов в виноделии // М.: ЦНИИТЭИПищепром. 1978 № 8. C. 1-5.

5. Литвинов А.К. Исследование работы гидроциклонов при осветлении виноматериалов: автореф. дис. на соискание учен. степени канд. техн. наук: спец. 05.02.14 «Машины и аппараты пищевых производств» / А.К. Литвинов. М. 1980.25 с.

6. Chiarificatori e dekanter nelle cantine vinicole. Italia. Milano.:1983. $40 \mathrm{c}$.

7. Системы и технологические процессы от ГЕА Вестфалия Сепаратор для виноделия. Каталог концерна GEA GROUP. M.: ООО «ГЕА Вестфалия Сепаратор Си Ай Эс». 2013. 66 с. C. $41-42$

8. Ковалевский К.А. Гидроциклон экстрактора Р3-ВЭА. // Садоводство. Виноградаство и виноделие Молдавии. 1981.

9. Виноградов В.А., Шанин А.Д., Ковалевский К.А., Мамай О.И. Комплексная технология переработки дрожжевых осадков и нестандартного плодово-ягодного сырья // Магарач. Виноградарство и виноделие. 2012. № 1. С. 32-34.

\section{References}

1. Kasatkyn, A.H. (1971) Osnovnye protsessy i apparaty khimicheskoi tekhnolohii. M.: Khimiia. 784

2. Boholiubskyi, S.D. (1986) Yssledovanie raboty hydrotsyklonov i ikh sovershenstvovanie. Ekspress-informatsiia. Zarubezhnyi opyt. M.: TsINTIKhIMNEFTEMASh. 6.

3. Vinohradov, V.A. (2002) Oborudovanie vinodelcheskikh zavodov. Simferopol: Tavrida. 1, 416.

4. Zaichik, Ts.R., Litvinov, A.K., Kaznacheeva, O.A. (1978) Primenenie hidrotsiklonov v vinodelii. M.: TsNIITEIPishcheprom. 8, $1-5$

5. Litvinov, A.K. (1980) Issledovanie raboty hidrotsiklonov pri osvetlenii vinomaterialov: avtoref. dis. na soiskanie uchen. stepeni kand. tekhn. nauk: spets. 05.02.14 «Mashiny i apparaty pishchevykh proizvodstv». A.K. Litvinov. M. 25.

6. Chiarificatori e dekanter nelle cantine vinicole. Italia. Milano.:1983. 40.

7. Sistemy i tekhnolohicheskie protsessy ot HEA Vestfaliia Separator dlia vinodeliia. Kataloh kontserna GEA GROUP. M.: OOO «HEA Vestfaliia Separator Sy Ai Es». 2013. 66.

8. Kovalevskii, K.A. (1981) Hidrotsiklon ekstraktora R3-VEA. Sadovodstvo. Vinohradarstvo i vinodelie Moldavii. 6, 41-42.

9. Vinohradov, V.A., Shanin, A.D., Kovalevskii, K.A., Mamai, O.I. (2012) Kompleksnaia tekhnolohiia pererabotki drozhzhevykh osadkov i nestandartnoho plodovo-iahodnoho syria // Maharach. Vinohradarstvo i vinodelie. 1, 32-34.

\section{МЕТОДИКА РОЗРАХУНКУ ПРОЦЕСУ КОНЦЕНТРУВАННЯ ХАРЧОВИХ РОЗЧИНІВ ТА ЕКСТРАКТІВ У МІКРОХВИЛЬОВОМУ ВАКУУМ-ВИПАРНОМУ АПАРАТІ}

\author{
Ружицька Н.В., к.т.н., ассистент, \\ Різниченко Т.А., аспірант, Войтенко О.К., к.т.н., доцент \\ Одеська національна академія харчових технологій, м. Одеса
}

\begin{abstract}
Анотація. Для інтенсифікації процесу вакуум-випарювання запропоновано забезпечити рівномірність енергопідведення $і$ виключити проміжний теплоносій за рахунок використання мікрохвильових технологій. При мікрохвильовому підведенні енергія надходить безпосередньо до молекул води в продукті, осередки пароутворення виникають у всьому об'ємі і виконують функцію гріючої поверхні.

В результаті експериментального моделювання проиесу мікрохвильового вакуум-випарювання розчинів иукру одержано коефічієнти критеріального рівняння процесу.

Наведено методику розрахунку процесу вакуум-випарювання в умовах дії мікрохвильового поля. В основі методики розрахунку критеріальне рівняння процесу випарювання в умовах вакууму та мікрохвильового енергопідведення, змінними якого є число енергетичної дї, безрозмірний параметр площі дзеркала продукту та безрозмірний тиск. Алгоритм включає розрахунки теплофізичних властивостей продукту, геометричних характеристик ємності, швидкості видалення вологи, поточну концентрачію сухих речовин у розчині, необхідну тривалість процесу, витрати енергї та економічні характеристики. Цикли розрахунку повторюються поки концентрація розчину в апараті сягне заданого для кінцевого продукту значення.
\end{abstract}

